\title{
国 \\ Green Washing \\ ESG Risk Disclosure and the Risk of
}

Chitra S De Silva Lokuwaduge ${ }^{1} \&$ Keshara M De Silva ${ }^{2}$

\begin{abstract}
There have been growing calls from capital market participants, regulators and other stakeholders around the globe for transparent measurement and disclosure of information about financially material environmental, social and governance (ESG) Risks. Diverse approaches to and objectives of sustainability standards and frameworks pose the threat of increasing greenwashing, a term which encompasses a wide range of actions which exaggerate and misrepresent 'green' credentials . Traditional financial reporting is regulated, mandatory, and required to meet the qualitative characteristics; relevance, reliability, comparability, materiality and understand ability. However, ESG reporting is problematic due to reporting quality which does not meet the above criteria. Apart from that ESG reporting is not regulated in most part of the world. A global framework is needed to prevent fragmentation, provide greater comparability, transparency and reduce the complexity of ESG disclosure which could mitigate the risk of greenwashing as the ESG is increasingly considered to be a fundamental part of effective and sustainable business performance. ${ }^{3}$
\end{abstract}

Keywords: ESG, Sustainability reporting, ESG disclosure, Green washing, ESG strategy JEL Classification: M40, Q01, Q20

\footnotetext{
${ }^{1}$ Victoria University, Melbourne, Australia

${ }^{2}$ University of Melbourne, Australia

3 The Authors acknowledge the funding support from the AFAANZ for this project
} 


\section{INTRODUCTION}

Environmental Social and Governance (ESG) related disclosure, also sometimes known as Corporate Social Responsibility (CSR), has rapidly grown over the last two decades. Since the early 80 s corporate sustainability has evolved from expressing good intentions and looking for internal operational efficiencies to addressing critical business issues involving a complex network of strategic relationships and activities (Kiron et al., 2015) and most of the research use the term CSR to discuss the ESG disclosure as ESG is the latest form of CSR . ESG disclosures are voluntary in most parts of the world, and this provides fertile territory for research into the motivational aspects for these disclosures. The main focus of the research has been whether these disclosures constitute the discharge of accountability or are part of a legitimation process (Van Der Laan, 2009; Lokuwaduge and Heenetigala 2017). Due to the intensified worldwide attention on unethical corporate behaviour and corporate collapses, companies are being asked to 'account' in various forms about their ESG related activities and their impacts. This shift from predominantly voluntary information provision to demanded information can be seen as a consequence of the increasing pressures on corporations to be 'socially responsible'. This demanded information serves to constrain corporate discretion in defining the scope and nature of disclosure. Regulatory agencies, ethical or socially responsible investment fund managers, ratings agencies and other interested parties are requesting social information from corporations.

\section{BACKGROUND}

The number of firms that provide information related to environment and social disclosures has dramatically risen as Corporate Social Responsibility (CSR) reporting during the last two to three decades. Addressing sustainability issues have become more global and pivotal to success, companies are now realising that they cannot ignore the wave or cannot "go it alone" to fulfil the wider stakeholder expectations, and that business should join their strategic networks to tackle some of the toughest ESG issues. These include climate change, greenhouse gas emission, access to non-renewable resources, avoiding human rights violations (Kiron et al., 2015) and transparent and accountable governance mechanisms.

Transparent measurement and disclosure of ESG performance are now considered to be a fundamental part of effective business management. With the rise of sustainability reporting and the complexity of the reporting measures, the reliability of this information became a major issue among relevant stakeholders. Corporate bodies use different types of reports such as annual reports, sustainability reports, integrated reports or the company website to disclose their non-financial information, such as ESG using different frame works and measures. This inconsistency of reporting creates the opportunity for potentially misleading disclosures, encompasses a wide range of actions which exaggerate and misrepresent 'green' credentials which is commonly explain as 'greenwashing'. There have been growing calls from capital market participants, regulators and other stakeholders around the globe for transparent measurement and disclosure of information related to financially material ESG risks and opportunities.

\section{THE GREENWASHING PHENOMENA}

Concerns over greenwashing has increased globally due to a lack of international standards on ESG-related taxonomy. In the environmental context, potentially misleading disclosures and claims are known as 'greenwashing', a term which encompasses a wide range of actions which 
exaggerate and misrepresent 'green' credentials. It may be a marketing action designed to create a favourable impression about a company or its products (Corrs Chambers Westgarth 2021a). While at the more nefarious end, it is conduct designed to mislead and deceive investors and customers by using terms such as "clean energy".

Gregory (2021, p.2) identified some common definitions of greenwashing in the literature and following are some of these definitions : selective disclosure; decoupling, where the firm has a negative performance but provides a positive communication about their performance; Cognitive legitimacy based on the shared taken-for-granted assumptions of an organisation's societal environment, moral legitimacy, and pragmatic legitimacy (benefiting constituents); product/service-level claim greenwashing, which uses textual arguments that explicitly or implicitly refer to the ecological benefits of a product or service to create a misleading environmental claim; firm level greenwashing, which consists of (a) belonging to an inherently unsustainable business, but promoting sustainable practices or products; (b) diverting attention from sustainable issues through the use of advertising and promoted research; (c) affecting regulations or governments in order to obtain benefits in areas of sustainability; (d) proclaiming sustainability accomplishments or commitments that are required by laws and regulations; and (e) taking advantage of sustainability reports in order to twist the truth or project a positive image".

\section{ESG REPORTING LANDSCAPE IN THE AUSTRALIAN CONTEXT}

According to Corporate Governance Principles and Recommendations, 4th Edition (ASX Corporate Governance Council 2019), ASX Corporate Governance Council- Principle 7 Recognise and manage risk explains that "A listed entity should establish a sound risk management framework and periodically review the effectiveness of that framework". Further Recommendation 7.4 says, "A listed entity should disclose whether it has any material exposure to environmental or social risks and, if it does, how it manages or intends to manage those risks. However, this Principle does not require a listed entity to publish an "integrated report" or "sustainability report". "An entity that does publish an integrated report in accordance with the International Integrated Reporting Council's International Framework, or a sustainability report in accordance with a recognised international standard, may meet this recommendation simply by cross-referring to that report. How an entity manages environmental and social risks can affect its ability to create long-term value for security holders. Investors are calling for greater transparency on the environmental and social risks faced by listed entities, so that they can properly assess the risk of investing in those entities. Australian Securities and Investment Commission (ASIC 2019) in Section E of RG247 gives guidance on good disclosure practices. Directors and preparers of Annual Report (AR) should present the narrative and analysis in a way that maximises its usefulness to shareholders. As a matter of good practice, an AR should present information in a single section, and in a manner that is: complementary to and consistent with the annual financial report, balanced and unambiguous, clear, concise and effective.

The IFRS Foundation Trustees' sustainability reporting initiative in 2021 (which Australia is also a partner in) is the latest development in the ESG reporting landscape and they wanted to assess the demand for global sustainability standards; whether there is a need for global sustainability standards; what role the Foundation might play in the development of such standards and what the scope of that role could be. Any frame work should facilitate and guide companies and their stake holders, and provide a more complete picture of long-term value creation while meeting investor needs for comparable, consistent, and reliable information. 
"When considering the concept of materiality, it is important to determine the objectives of sustainability reporting, what information is needed to achieve those objectives and which stakeholders will use the information reported by companies. Qualitative characteristics of useful sustainability information also need to be developed, drawing upon principles set out in existing frameworks such as the TCFD, the SASB, the International Framework and the Sustainable Development Goals Disclosure recommendations (SDGD)" (IFRS Foundation 2020, p13).

Regulators and standard setters in Australia have increased guidance and' encouragement to disclose' on climate risk. Currently there are no explicit requirements to provide climaterelated information in the Annual Report, but there are a number of implicit requirements or recommendations that are likely to be significant for a climate-exposed business. With growing investor and community expectations on companies to 'do the right thing', it is important that best practice be followed (KPMG 2020).

\section{THEORETICAL FOUNDATION}

Theories concerning information flows between organisations and society are broad and overlapping (Gray et al, 1995). Social and political theories that focus on the role of information and disclosure in the relationships between countries, organisations, states, groups and individuals are considered most appropriate in explaining corporate reporting (Deegan, 2000: Deegan and Blomquist 2006: Gray et al, 1996). According to Blomquist and Deegan (2000, p. 7) "Society, politics, and economics are inseparable so that issues, such as economic issues, cannot be considered in isolation from social and environmental issues". The political economy perspective perceives corporate reports as social, political and economic documents. 'They serve as a tool for constructing, sustaining and legitimising economic and political arrangements, institutions, and ideological themes which contribute to the corporation's private interests. Disclosures have the capacity to transmit social, political and economic meanings for a pluralistic set of report recipients" (Guthrie and Parker, 1990, p.166). According to Miller (1994, p 16) political economic theory "emphasises the fundamental interrelationship between political and economic forces in society". This political and economic interrelationship leads to information asymmetry and greenwashing.

Stakeholder theory and legitimacy theory have developed from the broader political economic theory perspective (Gray et al, 1996; Deegan and Blomquist 2006; Van Der Laan 2009) and even though they both focus attention on the nexus between the organisation and its operating environment (Neu et al, 1998.), there are differences between stakeholder and legitimacy theory. Legitimacy theory deals with "perceptions and the processes involved in redefining or sustaining those perceptions and can accommodate notions of power relationships and discourses at a global level" (Moerman and Van Der Laan, 2005, p. 376) while stakeholder theory approach is suggested as the most suitable theory to explain managerial behaviour in relation to engagement with identified stakeholders. These two theoretical perspectives should not be regarded as clearly distinct and delineated. It is more appropriate to consider them as overlapping perspectives on issues situated in a framework of assumptions supporting 'political economic perspective' (Deegan, 2000: Gray et al, 1995, Van Der Laan, 2009). Most of the prior literature has mainly explain ESG reporting based on legitimacy theory or stakeholder theory (Chelli et al. 2014; Owen, 2007; Parker, 2005; Sharma, 2013) and reveal there is a clear link between these two theories (Amran et al. 2015; Soobaroyen and Mahadeo, 2016). 


\subsection{Stakeholder Theory}

"Stakeholder theory attempts to articulate a fundamental question in a systematic way: which groups are stakeholders deserving or requiring management attention, and which are not?" (Mitchell et al, 1997, p. 855) which acknowledges the complex relationships between an organisation and its stakeholders (Lokuwaduge and Heenentigala, 2017). These relationships involve responsibility and accountability (Gray et al, 1996). "Stakeholder analysis enables identification of those societal interest groups to whom the business might be considered accountable, and therefore to whom an adequate account of its activities would be deemed necessary" (Woodward and Woodward, 2001, p.1). Stakeholder theory has been advanced "...on the basis of its descriptive accuracy, instrumental power, and normative validity. These three aspects of the theory, although interrelated, are quite distinct; they involve different types of evidence and argument and have different implications" (Donaldson and Preston, 1995, p. 65). When the disclosure is organisation centred, descriptive aspect referred it as the managerial branch of stakeholder theory (Deegan, 2000) because "information...is a major element that can be employed by the organisation to manage (or manipulate) the stakeholder in order to gain their support and approval, or to distract their opposition or disapproval" (Gray et al, 1996, p.46).

According to Van Der Laan, (2009, p18), "Stakeholder analysis involves identifying organisational stakeholders that have some rights to demand information, ranking and prioritising their interests. (Gray, 2001) This ranking or prioritisation may not be overt, obvious or conscious, but more a heuristic for understanding why some of these groups have their information needs met and others do not." Study of Neu et al (1998) on the environmental disclosures of Canadian public companies operating in environmentally 'sensitive' industries concluded that "the level and type of environmental disclosure contained in the annual reports is influenced primarily by an organisation's relevant publics, and that the communication strategies adopted by the organisation are influenced by the multiplicity and power of these different publics" (Neu et al, 1998, p. 274). This also confirm the importance of stakeholder power and suggests that "because of these different publics, the relationship between environmental disclosures and an organisation's methods of operations and output will always be partial in that these disclosures attempt to emphasise environmental successes, re-frame challenges raised by important publics and ignore challenges raised by marginal publics" (Neu at al, 1998, p. 274). According to stakeholder theory, firms are committed to offer transparent information on the impact of their activities to their stakeholders (Dubbink et al. 2008). O'Dwyer and Owen (2005) underline the reluctance to address specific stakeholders and the absence of their participation.

\subsection{Legitimacy Theory}

According to Matthews (1993) legitimacy is defined as "the congruence between the social values associated with or implied by their activities and the norms of acceptable behaviour in the larger social system in which they are a part of: Organisations seek to establish congruence between the social values associated with or implied by their activities and the norms of acceptable behaviour in the larger social system in which they are a part. In so far as these two value systems are congruent, we can speak of organisational legitimacy. When an actual or potential disparity exists between the two value systems, there will be a threat to organisational legitimacy" (Mathews 1993, p.350).

From legitimacy theory perspective, many scholars justify ESG reporting as a mechanism by which firms manage their legitimacy and reputation (Clarke and Gibson-Sweet, 1999; Hooghiemstra, 2000; Woodward et al. 1996; de Silva Lokuwaduge and de Silva, 2020). These 
practices could be substantive to align organisational strategies and processes with social norms or symbolic to positively influence stakeholders' perceptions to gain legitimacy or licence to operate (Gray, 2010; de Silva Lokuwaduge and de Silva, 2020), leading key stakeholders to mistakenly believe that the company is committed to societal expectations (Michelon et al. 2015; Ball et al.2000; Gray, 2010) which leads to and identify as corporate greenwashing.

A vast number of market-based research studies frame ESG disclosure as a symbolic tool (Cho and Patten, 2007; Patten, 2002) firms use with the intention to influence stakeholders' perceptions of corporate commitment to ESG reporting (Owen, 2007; Ntim and Soobaroyen, 2013; Lokuwaduge and Heenentigala, 2017). In these cases, ESG is considered to be a form of voluntary disclosure that is valuable to firms' stakeholders and investors (Clarkson et al. 2008; Dhaliwal et al., 2012; Moser and Martin, 2012) from a supply perspective (Van Der Laan 2009). Boiral and Gendron (2011) consider environmental and social disclosure to be a "rational myth" that reflects the ceremonial and superficial adhesion to apparently rational structures and is primarily intended to meet external pressures and reinforce organisational legitimacy in response to normative, coercive, and mimetic pressures (Martínez-Ferrero and García-Sánchez, 2017) which aligns with institutional pressure. Institutional pressure is an important driver towards sustainability reporting (Tate et al., 2010). Cho et al. (2014) posit that it is more likely associated with the inclusion of the company in the Dow Jones Sustainability Index and, therefore, to be perceived as "greener", although some have expressed a certain degree of scepticism about this (Guthrie and Parker, 1989). Other investigations (Cho et al., 2012; Hopwood, 2009; Merkl-Davies and Brennan, 2011; Moneva et al., 2006) state that these practices are nothing more than a tool to manage corporate image rather than a substantive improvement in the accountability process. This also aligns with the argument that ESG reports are used as an impression management tool rather than for true accountability (Beattie and Jones, 1992; Cho et al. 2012), which could have the "purpose of controlling or manipulating the attributions and impressions formed of that person by others" (Tedeschi and Riess, 1981, p. 3) is a method of greenwashing.

Institutional theory, resulting from legitimacy theory, describes the tendency to take structures and procedures for granted without questioning them. The adaptation to these practices and the homogeneity of behaviours is known as isomorphism. Neo- institutional theory (DiMaggio and Powell, 1983) also proves useful for scrutinising the assurance of corporate information because it is grounded in the relationship between different institutions.

\section{DISCUSSION}

ESG issues have been viewed as non-financial risks that have been undertaken by organisations as CSR measures to mitigate any ethical, sustainability and environmental impacts until recently. There is a growing body of stakeholders, including regulators, NGOs and investors, who evaluate ESG issues as material financial, legal, commercial and reputational risks on company assets. This shift drives responsibility for ESG considerations into organisation's strategy and risk framework. The intent of ESG reporting is important in understanding the quality of reporting. This study analyses the prior studies related to ESG reporting using two main lenses. The demand of information by stakeholders; and the supply of information to stakeholders are used to analyse the quality and the intention of ESG reporting. The demand lens provides ESG related information to meet the expectations of the wider stakeholders so that they can evaluate the ESG implications alongside the economic performance of corporate activities (Romero et al., 2019; Sotorrío and Fernández Sánchez, 2010), which emphasise the companies' accountability to its wider stakeholders. This behavior which involves a real 
change in processes, practices and the improvement in quantity and quality of ESG information in order to respond to stakeholders' demands (Merkl-Davies and Brennan., 2011), is related to the management approach to sustainability.

On the other hand, the supply lens analyses ESG reporting as a driver to build trust, to improve processes and systems, to enhance the progress on the companies' vision and strategy (Romero et al 2019), to reduce compliance costs, and to create competitive advantages (Global Reporting Initiative [GRI], 2013), which may become a symbolic managerial tool (Bebbington, Larrinaga, and Moneva, 2008; Marquis and Qian, 2014) to enhance the company's image instead of an information facilitation tool to assess companies accountability for sustainability (Romero et al., 2019 ). Brennan et al., (2009) conceptualise symbolic management narratives as a tool aims at modifying the readers' impression, also referred as impression management in prior litreture (Bebbington et al., 2008; Marquis and Qian, 2014; Romero et al 2019). MerklDavies and Brennan (2011) explain impression management as a biased, self-serving, symbolic management and accounting rhetoric which further confirms that impression management is a symbolic management involving "any behaviour by a person that has the purpose of controlling or manipulating the attributions and impressions formed of that person by others" (Tedeschi and Riess, 1981, p. 3) which explains greenwashing behaviour.

"...disclosure is one response to a perceived threat to or gap in organisational legitimacy. Disclosure would not be required unless a section of society or 'relevant' public is questioning the appropriateness of the organisation's output, methods or goals. In other words, if society's perception of the organisation is aligned with the way the organisation wishes to be perceived, there is no legitimacy gap and hence no motivation to disclose or to seek to legitimate an organisation's output, methods or goals" (Van der Laan 2009, p. 22).

Edgar et al., (2018) argue that private-sector organisations appear to conform to social rules and norms for legitimacy, which motivates impression management (Merkl-Davies and Brennan, 2011). ESG disclosure is still a voluntary requirement in Australia, other than a few regulatory requirements to disclose certain information related to certain industries such as mining and, due to this voluntary nature of disclosure, companies can decide and set forums and agendas to disclose ESG information. According to Van der Laan (2009, p.21) "Corporations decide what to disclose, when to disclose and how to disclose as well as the medium. These decisions are made at an 'abstract level' without necessarily identifying the information needs of organisational stakeholders". Deegan (2002) analyses the motivation for corporate social reporting disclosure using legitimacy theory and confirms the view of Dowling and Pfeffer, (1975) that companies perceive the information needs of the broader society and strategically deliver these information, ensuring that it is aligned with the perception desired by the company (Amor-Esteban et al., 2018). "Thus, an image is constructed through communication via the social reporting process ... However, this critique may be a natural consequence of the analysis of motivations for .... (ESG)" (Van der Laan 2009, p. 21).

This duality in the purpose of reporting creates the opportunity for greenwashing and researchers (Clarkson et al., 2008; Michelon et al., 2015) emphasise the importance of a common model for ESG reporting as a legitimacy tool (Heenetigala et al., 2017) and a commonly accepted framework to measure the quality of the ESG reporting instruments for accountability and action as there is no generally accepted reporting standards for ESG reporting.

The research of Romero et al., (2019) on ESG reporting in Spain found that companies that present separate sustainability reports (SR) or integrated reports (IR) provide higher quality 
information compared to the companies that include their ESG information within their annual report. This study also reports the need for a common ESG reporting framework in order to achieve the objectives of the sustainability reporting. The GRI framework is broadly used among companies that publish stand-alone SRs (King and Bartels, 2015) and includes social, environmental, and economic information. They do not include these disclosures within the annual financial statements. International Integrated Reporting Council (IIRC) developed the Integrated Reporting framework, and this appears to be the latest reporting approach (Willis, Campagnoni, and Gee, 2015).IR gives a holistic view of the organisation as it includes the performance, framework of disclosure and strategy in the context of its material social and environmental issues (IRCSA, 2012). Although IIRC highlights the shareholders as the main addressees of the IR, this report also provides useful ESG information and their impact to wider stakeholders. Wide stakeholder engagement is one of the main fundamentals of the integrated reporting process (Deloitte, 2014). Alternatively, companies may report on sustainability issues by adding specific information within the AR. Integrated reporting should provide users with detailed explanations of financial and non-financial (ESG) risks related to the organisation in order to generate sustainable returns (IIRC, 2013; de Villiers and Alexander 2014; Van Zijl et al., 2017). ESG risks should be clearly linked to the entity's strategy and the business model (Stubbs and Higgins, 2014; Raemaekers et al., 2016).

According to Van Der Laan (2009, p.21) "The advent and proliferation of social reporting guidelines and frameworks has not served to mitigate the control that corporation's exercise over this process. Corporations 'cherry pick' what they will or will not adopt from within these frameworks and guidelines. A stunning example of this managerial discretion is the 2001/2002 British American Tobacco (BAT) Social Report. BAT employed the AccountAbility AA1000 framework to guide the process of stakeholder engagement for its social report. It supported this process with the Global Reporting Initiative's (GRI) guidelines for categories and aspects to report against. And yet, the GRI category Products and Services, which is concerned with the major social issues and impacts associated with the use of principal products and services (GRI, 2002, p. 35) is omitted in the BAT Social Report 2001/2002" while the principal product of BAT is cigarettes.

Michelon et al., (2015) use a sample of British companies for the period 2005-2007 and report ESG reporting is just a symbolic rather than a substantive approach to sustainability reporting. Maniora (2017) studied the effect of the integration of sustainability issues and the related performance changes and finds there is no benefit from switching from SR to IR if the behavioural intention remains the same while Pistoni et al (2018) conclude that IR quality is low compare to SR. Dowling and Pfeffer (1975) define the SR concept as the outcome of both the process of legitimation by the organisation and by the actions affecting relevant norms and values taken by relevant stakeholders but that social norms and values are not static and organisation should act accordingly to meet the societal demand .

\section{CONCLUDING REMARKS}

ESG is one of the main strategic imperatives for business leaders today. How can business leaders balance their business goals and the activities of commercial enterprises with ESG principles as the main focus of the ESG reporting landscape? The number of firms that provide information related to environment and social disclosures has dramatically risen as ESG reporting or CSR reporting during the last two to three decades. Corporate entities worldwide have realised the increasing importance of the social license to operate and that investors do not make their investment decisions only on the expectations of profit but also taking into 
consideration how companies address their ESG related risks, how they incorporate the ESG into their strategic activities and how they report on them.

Integrated reporting (IR) is the most recent development in the ESG reporting landscape. IR shifts the historical focus of financial reporting to a forward- looking value creation process. According to International Integrated Reporting Committee (IIRC, 2013), the reporting entity should illustrate how management uses financial, human, intellectual, natural and social capital in the value creation process (IIRC, 2013).

According to the International Federation of Accountants IFAC (2021) study of the global state of sustainability assurance of 100 largest companies, $91 \%$ of them reported some level of sustainability information, and that $51 \%$ of them provided some level of sustainability assurance. This study outlines significant differences across jurisdictions. There is a wide, and widespread, dispersion among sectors and some sectors such as energy, technology and telecommunications, present the highest percentage of sustainability reports.

In the Australian context some allegations of greenwashing are under scrutiny such as climate related disclosures, financial and other disclosures regarding exposure to climate risk, green marketing of products and brands which makes representations about products or practices being environmentally friendly, sustainable or ethical, representations of corporate goals in relation to drivers such as alignment with Paris Agreement of net zero or other emissions reductions targets by a specified date. If not carefully managed, each of these elements has the potential to become misleading or deceptive, or a breach of relevant reporting obligations.

The International Organisation of Securities Commissions, which ASIC is also participating in, has established a Sustainable Finance Task Force (SFTF) to address greenwashing, the latest focus is the misleading or deceptive conduct allegations. In addition, each of the above situations raises the potential for actions from a broad range of possible claimants, including class actions, litigants and regulators such as the: Australian Competition and Consumer Commission (ACCC), Australian Securities and Investments Commission (ASIC), Australian Prudential Regulation Authority (APRA). Actions targeting greenwashing behaviours are most likely to be brought under Australian Consumer Law, or the ASIC Act (Corrs Chambers Westgarth 2021b).

Limited and imperfect information about firm ESG performance, complex and multiple ESG reporting frameworks and measurements (Alrazi et al., 2015) and the uncertainty about regulatory punishment for greenwashing, contribute to greenwashing. Regulators and NGOs should take action to improve the awareness of the consequence of engaging in greenwashing.

Addressing sustainability issues have become more global and pivotal to success, companies are now realising that they cannot ignore the wave or can't go alone to fulfil the wider stakeholder expectations, and business should join their strategic networks to tackle some of the toughest ESG issues, such as climate change, greenhouse gas emission, access to nonrenewable resources, avoiding human rights violations (Kiron et al., 2015) and transparent and accountable governance mechanisms. Transparent measurement and disclosure of ESG performance are now considered to be a fundamental part of effective business management. With the rise of sustainability reporting and the complexity of the reporting measures, the reliability of these information became a major issue among relevant stakeholders. Yet, the complexity surrounding these disclosures has made it difficult to develop a comprehensive solution for the credibility of ESG reporting that is urgently needed. 


\section{REFERENCES}

Agranoff, R. and McGuire, M. (1998). Multinetwork Management: Collaboration and the Hollow State in Local Economic Policy. Journal of Public Administration Research and Theory, 8, 67-91. https://doi.org/10.1093/oxfordjournals.jpart.a024374

Alrazi, B., De Villiers, C., and van Staden, C. J. (2015). A comprehensive literature review on, and theconstruction of a framework for environmental legitimacy, accountability and proactivity. Journal of Cleaner Production, 102, 44-57. -57.

https://doi.org/10.1016/j.jclepro.2015.05.022

Australian Securities and Investment Commission (ASIC) 2019 Regulatory Guide 247 Effective disclosure in an operating and financial review august 2019 https://download.asic.gov.au/media/5230063/rg247-published-12-august-2019.pdf

ASX Corporate Governance Council 2019 Corporate governance principles and recommendations. 4th Edition February 2019

https://www.asx.com.au/documents/asx-compliance/cgc-principles-andrecommendations-fourth-edn.pdf

Amran, A., Ooi, S. K., Mydin, R. T., and Devi, S. S. (2015). The impact of business strategies on online sustainability disclosures. Business Strategy and the Environment, 24(6), 551-564. https://doi.org/10.1002/bse.1837

Amor-Esteban, V., Galindo-Villardón, M. P., and David, F. (2018). Study of the importance of national identity in the development of corporate social responsibility practices: A multivariate vision. Administrative Sciences, 8(3), 50-67. https://doi.org/10.3390/admsci8030050

Ball, A., Owen, D.L and Gray, R.H. (2000). External transparency or internal capture? The role of third party statements in adding value to corporate environmental reports.

Business Strategy and the Environment, 9 (1), 1-23. https://doi.org/10.1002/(SICI)1099-0836(200001/02)9:1<1::AID-BSE227>3.0.CO;2$\underline{\mathrm{H}}$

Beattie, V., and Jones, M. J. (1992). The use and abuse of graphs in annual reports: Theoretical Frameworkand Empirical Study. Accounting and Business Research, 22(88), 291-303. https://doi.org/10.1080/00014788.1992.9729446

Bebbington, J., Larrinaga, C. and Moneva, J.M., 2008. Corporate social reporting and reputation risk management. Accounting, Auditing \& Accountability Journal. 21(3),337-361. https://doi.org/10.1108/09513570810863932

Blomquist, C. and Deegan, C. (2000), "Stakeholder influence on corporate reporting: An exploration of the interaction between the World Wide Fund for Nature and the Australian minerals industry", Working Paper.

Boiral, O., and Gendron, Y. (2011). Sustainable development and certification practices: lessons learned andprospects. Business Strategy and the Environment, 20(5), 331-347. https://doi.org/10.1002/bse.701

Chelli, M., Richard, J., and Durocher, S. (2014). France's new economic regulations: Insights from institutional legitimacy theory. Accounting, Auditing and Accountability Journal, 27(2), 283-316. https://doi.org/10.1108/AAAJ-07-2013-1415

Cho, C. H., and Patten, D. M. (2007). The role of environmental disclosures as tools of legitimacy: A researchnote. Accounting, Organisations and Society, 32(7/8), 639-647. https://doi.org/10.1108/SAMPJ-01-2014-0003

Cho, C. H., Michelon, G., and Patten, D. M. (2012). Impression management in sustainability reports: An empirical investigation of the use of graphs. Accounting and the Public Interest, 12, 16-37. https://doi.org/10.2308/apin-10249 
Cho, C. H., Michelon, G., Patten, D. M., and Roberts, R. W. (2014). CSR report assurance in the USA: An empirical investigation of determinants and effects. Sustainability Accounting, Management and Policy Journal, 5(2), 130-148. https://doi.org/10.1108/SAMPJ-01-2014-0003

Clarke, J., and Gibson-Sweet, M. (1999). The use of corporate social disclosures in the management of reputation and legitimacy: A cross sectoral analysis of UK top 100 companies. Business Ethics: A European Review, 8, 5-13. https://doi.org/10.1111/1467-8608.00120

Clarkson, P. M., Li, Y., Richardson, G. D., and Vasvari, F. P. (2008). Revisiting the relation between environmental performance and environmental disclosure: An empirical analysis. Accounting, Organisations and Society, 33(4/5), 303-327. https://doi.org/10.1016/i.aos.2007.05.003

Deegan, C., and Blomquist, C. (2006). Stakeholder influence on corporate reporting: An exploration of the interaction between WWFAustralia and the Australian minerals industry. Accounting, Organisations and Society, 31(4-5), 343-372. https://doi.org/10.1016/j.aos.2005.04.001

De Silva Lokuwaduge, C.S. and de Silva, K., 2020. Emerging corporate disclosure of environmental social and governance (ESG) risks: An Australian study. Australasian Accounting, Business and Finance Journal, 14(2), pp.35-50. https://doi.org/10.14453/aabfj.v14i2.4

De Villiers, C., and Alexander, D. (2014). The institutionalisation of corporate social responsibility reporting. The British Accounting Review, 46, 198-202. https://doi.org/10.1016/j.bar.2014.03.001

De Villiers, C., and Maroun, W. (2017). Sustainability accounting and integrated reporting. Oxfordshire:Routledge. https://doi.org/10.4324/9781315108032

Dhaliwal, D. S., Radhakrishnan, S., Tsang, A., and Yang, Y. G. (2012). Non-financial disclosure and analystforecast accuracy: International evidence on corporate social responsibility disclosure. The Accounting Review, 87(3), 723-759. https://doi.org/10.2308/accr-10218

DiMaggio, P. J., and Powell, W. W. (1983). The iron cage revisited: Institutional isomorphism and collectiverationality in organisational fields. American Sociological Review, 48, 147-160. https://doi.org/10.2307/2095101

Dowling, J. and Pfeffer, J., 1975. Organisational legitimacy: Social values and organisational behaviour. Pacific sociological review, 18(1), pp.122-136.

https://doi.org/10.2307/1388226

Dubbink, W., Graafland, J., and Van Liedekerke, L. (2008). CSR, transparency and the role of intermediate organisations. Journal of Business Ethics, 82(2), 391-406. https://doi.org/10.1007/s10551-008-9893-y

Edgar, V. C., Beck, M., and Brennan, N. M. (2018). Impression management in annual report narratives: the case of the UK private finance initiative. Accounting, Auditing and Accountability Journal, 31(6), 1566-1592. https://doi.org/10.1108/AAAJ-10-20162733

Global Reporting Initiative (GRI) (2002) Sustainability Reporting Guidelines. www.globalreporting.org

Gray, R. H., Kouhy, R., and Lavers, S. (1995). Corporate social and environmental reporting: A review of the literature and a longitudinal study of UK disclosure. Accounting, Auditing and Accountability Journal, 8,47-77. https://doi.org/10.1108/09513579510146996

Gray, R., Owen D. and Adams, C. (1996), Accounting and Accountability, Prentice Hall Europe, Great Britain. 
Gray, R. (2010). Is accounting for sustainability actually accounting for sustainability and how would we know? An exploration of narratives of organisations and the planet. Accounting, Organisations and Society, 35, 47-62. https://doi.org/10.1016/j.aos.2009.04.006

Gregory, R.P., 2021. When is greenwashing an easy fix?. Journal of Sustainable Finance and Investment, pp.1-24. doi.org/10.1080/20430795.2021.1907091

Corrs Chambers Westgarth 2021a. Corporate' greenwashing' the latest target for climate change litigation, 02 September 2021. https://www.corrs.com.au/insights/corporategreenwashing-the-latest-target-for-climate-change-litigation accessed on 5th Jan 2022

Corrs Chambers Westgarth 2021b. ESG A guide for General Counsel November 2021.https://www.corrs.com.au/site-uploads/images/PDFs/Insights/ESG-A-guidefor-General-Counsel-November-2021.pdf accessed on 5th Jan 2022

Guthrie, J. and Parker, L.D. (1989) "Corporate Social Reporting: A Rebuttal of Legitimacy Theory", Accounting and Business Research, 19(76) pp. 343 - 352. https://doi.org/10.1080/00014788.1989.9728863

Guthrie, J. and Parker, L.D. (1990) "Corporate Social Disclosure Practice: A Comparative International Analysis", Advances in Public Interest Accounting, 4, . 159 - 176.

Heenetigala, K, Armstrong, A. DeSilva Lokuwaduge, C. and Ediriweera, A. 2017 Environmental, social and Governance Reporting, Eweje, G and Bathurst RJ CSR, Sustainability and Leadership New York and London, Routledge Ch. 9..172-198. 8 https://doi.org/10.4324/9781315525976-9

Hooghiemstra, R. (2000). Corporate communication and impression management-New perspectives whycompanies engage in corporate social reporting. Journal of Business Ethics, 27, 55-6. https://doi.org/10.1023/A:1006400707757

International Federation of Accountants (IFAC), American Institute of Certified Public Accountants (AICPA), Chartered Institute of Management Accountants (CIMA) (2021). The state of play in sustainability assurance June. Available at:https://www.ifac.org/knowledge-gateway/contributing-globaleconomy/discussion/state-play- sustainability-assurance

IFRS Foundation, 2020. Consultation Paper on Sustainability Reporting September 2020.

https://www.ifrs.org/content/dam/ifrs/project/sustainability-reporting/consultation-paper-onsustainability-reporting.pdf accessed on 20th Dec 2021

Kiron, D., Kruschwitz, N., Haanaes, K. and Reeves, M., 2015. Joining forces: Collaboration and leadership for sustainability. MIT Sloan Management Review, 56(3). (https://sloanreview.mit.edu/projects/joining-forces/\#chapter-7)

KPMG 2020 Climate disclosures within the Annual Reports: An Australian focus.https://assets.kpmg/content/dam/kpmg/au/pdf/2020/climate-disclosures-withinannual-report-australian-focus.pdf

Lokuwaduge, C. S. D. S., and Heenetigala, K. (2017). Integrating environmental, social and governance (ESG) disclosure for a sustainable development: An Australian study. Business Strategy and the Environment, 26(4), 438-450. https://doi.org/10.1002/bse.1927

Martínez-Ferrero, J., and García-Sánchez, I.M. (2017). Coercive, normative and mimetic isomorphism as determinants of voluntary assurance of sustainability reports. $\begin{array}{lllll}\text { International } \quad \text { Business } & \text { Review, } & 26, & 102-118 . & 18 .\end{array}$ https://doi.org/10.1016/j.ibusrev.2016.05.009

Matthews, M. R. (1993). Socially Responsible Accounting. UK, Chapman and Hall.

Marquis, C. and Qian, C., 2014. Corporate social responsibility reporting in China: Symbol or substance?. Organisation science, 25(1), pp.127-148. 
https://doi.org/10.1287/orsc.2013.0837

Merkl-Davies, D.M., Brennan, N.M. and McLeay, S.J., 2011. Impression management and retrospective sense-making in corporate narratives: A social psychology perspective. Accounting, Auditing and Accountability Journal.24(3), 315-344. https://doi.org/10.1108/09513571111124036

Michelon, G., Pilonato, S. and Ricceri, F., 2015. CSR reporting practices and the quality of disclosure: An empirical analysis. Critical perspectives on accounting, 33, .59-78. https://doi.org/10.1016/j.cpa.2014.10.003

Miller, P. (1994) Accounting as a Social and Institutional Practice: An Introduction. In Miller, P and A.G. Hopwood. Accounting as a Social and Institutional Practice, Cambridge University Press, 1-39.

Moneva, J., Archel, P., and Correa, C. (2006). GRI and the camouflaging of corporate unsustainability. Accounting Forum, 30, 121-137. https://doi.org/10.1016/j.accfor.2006.02.001

Moser, D. V., and Martin, P. R. (2012). A broader perspective on corporate social responsibility research in accounting. The Accounting Review, 87(2), 797-806. https://doi.org/10.2308/accr-10257

Neu, D., Warsame, H. and Pedwell, K. (1998), "Managing public impressions: environmental disclosures in annual reports", Accounting, Organisations and Society, 23( 3 ). 265282. https://doi.org/10.1016/S0361-3682(97)00008-1

Ntim, C. G., and Soobaroyen, T. (2013). Corporate governance and performance in socially responsiblecorporations: New empirical insights from a Neo-Institutional framework. Corporate Governance: An International Review, 21(5), 468-494. https://doi.org/10.1111/corg.12026

O'Dwyer, B., and Owen, D. (2005). Assurance statement practice in environmental, social and sustainability reporting: a critical evaluation. The British Accounting Review 37: 205229. https://doi.org/10.1016/j.bar.2005.01.005

Owen, D. L. (2007). Assurance practice in sustainability reporting. In J. Unerman, J. Bebbington, and B. O'Dwyer (Eds.), Sustainability accounting and accountability. 168-183. London: Routledge. https://doi.org/10.4324/NOE0415384889.ch9

Parker, L. D. (2005). Social and environmental accountability research: A view from the commentary box. Accounting, Auditing and Accountability Journal, 18(6), 842-860. https://doi.org/10.1108/09513570510627739

Patten, D. M. (2002). The relation between environmental performance and environmental disclosure: Aresearch note. Accounting, Organisations and Society, 27(8), 763-773. 3. https://doi.org/10.1016/S0361-3682(02)00028-4

Perego, P. (2009). Causes and consequences of choosing different assurance providers: an international study of sustainability reporting. International Journal of Management. 26 (3), 412-425.

Raemaekers, K., Maroun, W. and Padia, N., 2016. Risk disclosures by South African listed companies post-King III. South African Journal of Accounting Research, 30(1), pp.4160. https://doi.org/10.1080/10291954.2015.1021583

Romero, S., Ruiz, S., and Fernández-Feijoo, B. (2019). Sustainability reporting and stakeholder engagement in Spain: Different instruments, different quality. Business Strategy and the Environment, 28, 221-232. https://doi.org/10.1002/bse.2251

Sharma, N. (2013). Theoretical framework for corporate disclosure. Research Asian Journal of Finance and Accounting, 5(1), 183-196. https://doi.org/10.5296/ajfa.v5i1.3210

Soobaroyen, T., and Mahadeo, J. D. (2016). Community disclosures in a developing country: Insights from a neo-pluralist perspective. Accounting, Auditing and Accountability 
Journal, 29(3), 452-482. 2. https://doi.org/10.1108/AAAJ-08-2014-1810

Sotorrío, L.L. and Sánchez, J.L.F., 2010. Corporate social reporting for different audiences: The case of multinational corporations in Spain. Corporate Social Responsibility and Environmental Management, 17(5), pp.272-283. https://doi.org/10.1002/csr.215

Stubbs, W. and Higgins, C., 2014. Integrated reporting and internal mechanisms of change. Accounting, Auditing \& Accountability Journal, 27(7), pp.1090-1119. https://doi.org/10.1108/AAAJ-04-2013-1303

Tate, W. L., Ellram, L. M., and Kirchoff, J. F. (2010). Corporate social responsibility reports: A thematic analysis related to supply chain management. Journal of Supply Chain Management, 46(1), 19-44. https://doi.org/10.1111/j.1745-493X.2009.03184.X

The International Integrated Reporting Council (IIRC) (2013). The International <IR> Framework. Availiable at:http://www.theiirc.org/wp-content/up loads/2013/12/13-1208-THE-INTERNATIONAL-IR-FRAMEWORK-2-1.pdf

Tedeschi, J.T. and Riess, M., 1981. Identities, the phenomenal self, and laboratory research. Impression management theory and social psychological research, 3, p.22. https://doi.org/10.1016/B978-0-12-685180-9.50006-3

Van der Laan, S., 2009. The role of theory in explaining motivation for corporate social disclosures: Voluntary disclosures vs 'solicited' disclosures. Australasian Accounting, Business and Finance Journal, 3(4) 2-18.

Van der Laan S.J., Adhikari, A. and Tondkar, R.H., 2005. Exploring differences in social disclosures internationally: A stakeholder perspective. Journal of accounting and public policy, 24(2), pp.123-151. https://doi.org/10.1016/j.jaccpubpol.2004.12.007

Van Zijl, W., Maroun, W. and Wöstmann, C., 2017. Strategy disclosures by listed financial services companies: Signalling theory, legitimacy theory and South African integrated reporting practices. South African Journal of Business Management, 48(3), pp.73-85. https://doi.org/10.4102/sajbm.v48i3.37

Woodward, D. G., Edwards, P., and Birkin, F. (1996). Organisational legitimacy and stakeholder information provision. British Journal of Management, 7, 329-347. https://doi.org/10.1111/j.1467-8551.1996.tb00123.x

Woodward, D. and T. Woodward (2001) "The case for a political economy of accounting: A critique of the arguments", Conference Proceedings, British Accounting Association Conference, Nottingham, March 2001. 